\title{
PERFORMANCE OF CASINO FIRMS: EMPIRICAL ANALYSIS OF SELECTED EU COUNTRIES
}

\author{
Igor Stubelj ${ }^{1}$ \\ Luka Jeraša ${ }^{2}$ \\ Mateja Jerman ${ }^{3}$
}

DOI: https://doi.org/10.31410/tmt.2019.541

\begin{abstract}
The purpose of the paper is to analyse whether Slovene casino firms are successful in their business and whether their performance differs from their competitors. To this end, the authors performed an empirical analysis of Slovene, Croatian and Italian casino firms for the period 2013-2016. The results show that there is a significant difference in ROE ratio between Slovenia and Croatia. Croatian firms outperformed Slovenian casino firms. On the other hand, a significant difference in terms of ROE was not confirmed by the comparative analysis of Slovenian and Italian firms. A further in-depth analysis, which is grounded on DuPont scheme of financial ratios, shows additional significant differences between countries considered in the analysis. The results of the study indicate possibilities for future improvements of casinos' performance.
\end{abstract}

Keywords: gaming industry, casino firms, performance, performance analysis.

\section{INTRODUCTION}

$\mathrm{E}$ adington (2003) found that most regions of the world exploit casinos to address various economic objectives, including tourism development, economic development, tax revenue generation, job creation and foreign exchange enhancement. Slovenia is certainly among these countries. There are currently 36 gaming concessions in Slovenia, allowing organization of special games of chance. Special games of chance are being organized by 26 gaming halls with slot machines and 10 casinos (hereinafter casino firms) (Ministry of Finance of the Republic of Slovenia, 2018). Gaming industry is important for the Slovene economy for the following reasons. Businesses that organize special games of chance are an important part of the tourism industry. The taxes they pay are an important income for the local and state budget. We can justify the importance of the gaming industry for the Slovene economy based on the findings that ,among the European countries, Slovenia stands out for the high share that gross gaming revenues represent in GDP and for the high share of gross casino revenues in the gross revenues of all gaming activities" (Government of the Republic of Slovenia, 2010b, p. 20). Data from 2009 show that the share of total revenues generated by all casino firms amounted to $83 \%$ of revenues of all gaming activities (Government of the Republic of Slovenia, 2010b). It indicates that casinos and casino saloons generate the overwhelming part of total revenues in the industry. Revenues from special games of chance are important in generating Slovenia's GDP. At the same time, it should be noted that the casino industry is a highly export activity (since visitors to Slovenian casinos and casino saloons are mostly foreigners).

\footnotetext{
University of Primorska, Faculty of Management, Cankarjeva 5, 6000 Koper, Slovenia

Casino Portorož, Obala 75a, 6320 Portorož, Slovenia

University of Primorska, Faculty of Management, Cankarjeva 5, 6000 Koper, Slovenia
} 
Due to the social unacceptability in view of negative social effects of the gambling industry, the starting point for the valid regulation of gambling activities in Slovenia, is that gambling activities should be taxed more than other business activities. ${ }^{4}$ Consequently, concessionaires who organize special games of chance pay the gambling tax and concession fee (Government of the Republic of Slovenia, 2010b, p. 40).

In 2009, Slovene casino concessionaires warned that the position of gaming firms was deteriorating due to the exhaustion of the industry with excess tax burden. Given the economic environment in which Slovenian casino firms operate, the paper aims to analyse as to whether they are successful in their business and whether their performance differs from their competitors. Gaming industry is very differently regulated among countries of the EU. In 2006, the Swiss Institute for Comparative Law published a study commissioned by the European Commission on the characteristics of gambling on the EU market. It was noted that there are significant differences in taxation between EU Member States and that in most analysed countries the number of gambling operators is limited (Government of the Republic of Slovenia, 2009). European casinos have also, compared to U.S. casinos, high average tax rates on gaming revenues $(\mathrm{Gu}$, 2001; Eadington, 2011).

To the best of our knowledge, there is no comparative analysis of performance between Slovenian casino firms and foreign competitors. To achieve the purpose of our analysis, Slovenian, Croatian and Italian casinos were analysed. The analysis is grounded on publicly available secondary data - financial data from annual reports. The analysis was carried out for the period 2013-2016. In total, the sample includes 83 firms. The comparative analysis is grounded on the DuPont system of performance analysis. Statistical differences between selected firms were tested with a non-parametric test for independent samples.

The paper is organized as follows. Section 2 presents the theoretical background, focusing on determinants of casinos' efficiency and performance, characteristics of gaming industry in the EU, highlighting the environment of casino firms in Slovenia, Croatia and Italy. Section 3 covers the empirical analysis, where we present the methodology, hypothesis development, followed by the results. Section 4 comments the findings and section 5 ends with the concluding remarks.

\section{THEORETICAL BACKGROUND}

The field of gambling in Slovenia is not governed by the EU law, as it is regulated by each individual member state by striving for its values and goals (Government of the Republic of Slovenia, 2009, p. 8). This is why the regulation of gambling activity is not harmonised, but it varies between EU countries.

\section{DETERMINANTS OF CASINOS' EFFICIENCY AND PERFORMANCE}

To date only a few studies have been devoted to gaming efficiency for individual resorts, while studies which would make a comparative analysis between different resorts are lacking (Deng, et al., 2020). Different studies address different variables to examine casino efficiency. In accordance with Deng et al. (2020) these variables are the number of employees, expenses, capital,

4 According to Meich (2008), taxation is not just a revenue-producing device but also a policy-shaping device. Casinos must fairly contribute to the state budget, however excessive taxation could be a threat to the gambling industry. 
gambling equipment and casino square footage. All these were used as input variables. On the other hand, casino revenues, EBITDA (earnings before interests, taxes, depreciation and amortisation) deflated by assets, tax revenue and market value, and the number of customers, were used as the output variables.

In a recent study Deng et al. (2020) made an in-depth comparative analysis of gaming efficiency among two largest casino resorts, i.e. Macau and Las Vegas. They built a theoretical model, which includes internal and external factors of casino efficiency. Their empirical analysis is based on 15 largest casino groups in Macau and Las Vegas (generating approximately 90\% of total casino revenues in the two destinations). They found that gaming efficiency is significantly higher in Macau in comparison to Las Vegas. Macau gaming efficiency is significantly impacted by table games, while slot gaming contributes to gaming efficiency in Las Vegas. Non-gaming activities are also an important determinant of gaming efficiency in Las Vegas, while this is not the case in Macau. Both casino resorts evidenced a significant downturn in casino efficiency due to the global economic crisis.

Gu \& Gao (2006) analysed the casino product structure, revenue composition, assets productivity and financial returns of Macau versus gaming destinations in North America and Europe. They found that Macau must modify its casino product structure and revenue composition to ensure a fast but stable gaming revenue growth and retain its competitiveness. Macau may have to adjust its levy policy to maintain its attractiveness for new casino investors and operators as rivals in the same region use lower gaming levy to attract investors (Gu \& Gao 2006).

Lambert et al. (2010) performed an analysis of casino efficiency based on the sample of five U.S. States (Illinois, Indiana, Iowa, Louisiana, and Missouri). When these states legalized casinos, initially only riverboat casinos were permitted. Despite the fact that nowadays land casinos are permitted, the majority of casinos is still on riverboats. The authors evidenced that the location of a casino is an important determinant of its success. More efficient casinos are those which operate in larger and more densely settled urban areas, compared to those which operate in smaller and less densely settled areas.

Another study performed on a sample of U.S. casinos was made by Day-Yang et al. (2017). The authors performed a regression analysis and found that the variable "value of total assets" is significantly positively related to the performance of casino firms. Their results show that larger casinos are more successful in their business. The analysis is based on 24 U.S. listed firms and, data from the period 2004-2013.

$\mathrm{Gu}$ (2001) performed a comparative analysis of U.S. Nevada, Dutch and French casino firms. Findings show that Dutch and French casinos outperformed U.S. casinos, both in terms of efficiency and profitability. Selected European casinos had better results in revenues per slot per day, revenue per employee per day and net income per employee per day. The analysis was made on data from 1998. The author states that the result might be a consequence of a non-competitive European gaming market. U.S. casinos in contrast to European casinos operate in a different legal and market environment. U.S. casino firms are mostly private firms, while European casino firms are often state owned, they have marketing restrictions and a limited extent of competition.

An analysis of factors that lead to different performance was made on a sample of Slovenian casino firms (Assaf et al., 2013). They found that larger gambling firms compared to smaller 
ones were more successful. Similarly, casinos located near the state border, were more successful than others located inland, and those operating within the group were more successful than those operating individually.

\section{GAMING INDUSTRY IN THE EU}

Each EU country may decide how to regulate the gambling industry according to its strategic goals and orientations. There are thus major differences between the EU countries in the size and structure of the gambling market. For example, casinos are banned in Ireland (Government of the Republic of Slovenia, 2010b, p. 19). European casino industry is characterized by small municipal or regional monopolies, with an extensive presence of slot machines in locations outside casinos (Eadington, 2011).

The ownership structure and management of firms operating in the gambling industry is also quite different among EU Member States. In several EU Member States, casinos are managed either by the state or by a state-controlled operator (e.g. Germany, Greece, Finland, Hungary, Netherlands, and Sweden). On the other hand, in most EU Member States casino saloons are privately owned or operated by a local community, which can outsource management to a private operator (e.g. Italy, Spain). Usually, the number of casinos in each country is limited (Government of the Republic of Slovenia, 2010b, p. 36).

The gaming industry among EU Member States has been subject to specific duties (gaming taxes, licence fees, etc.). The types of taxes and tax bases vary considerably between EU Member States (Swiss Institute of Comparative Law, 2006). In accordance with the literature tax rates for casinos in the EU are high (Swiss Institute of Comparative Law, 2006; Gu, 2001; Eadington, 2011; Eadington, 2007).

Among the reasons for deteriorated performance of the gambling industry in Europe since 2008, the European Casino Association (2015, p. 5) cites the recession, restriction on smoking in casinos in some countries, illegal competition from online gambling providers, as well as high taxation on gambling activity. The latter originates from the past and since than it has not changed in several EU countries, although the business environment in the industry has changed significantly over the last decade (European Casino Association, 2015, p. 5).

\section{GAMING INDUSTRY IN SLOVENIA, CROATIA AND ITALY}

Slovenian gambling industry began to develop in 1964 with the opening of the Casino Portorož. Only in 1995, the new Gambling Act allowed Slovenian citizens to visit casinos. An important change of the Slovene Gambling Act followed in 2002. Until then casinos were exclusively state owned. Changes of the Act allowed private firms to establish gaming halls (for more details see Luin \& Hojnik, 2016). In the years that followed, many casinos were established. Until 2008 the business environment in the industry was favourable. The favourable conditions in the business environment for the most part of the period 2002-2008 are also confirmed by the data on the number of newly established gaming halls. In 2002, there were 10 gaming halls operating in Slovenia and 32 in 2008 (Ministry of Finance of the Republic of Slovenia, 2018). The situation has changed significantly in the subsequent years with the onset of the financial and economic crisis. Already in 2009, casino concessionaires warned that the position of gaming firms in Slovenia was deteriorating due to the exhaustion of the industry with excess tax burden. The 
economic crisis further jeopardized their operations (Government of the Republic of Slovenia, 2010a). It is not surprising, therefore, that in 2008 and 2013 we witnessed the compulsory settlement of Casino Portorož, followed by the bankruptcy of the Casino Maribor in 2009, and the bankruptcy of the Casino Ljubljana in 2010. The most important competitors of Slovene casino firms are those in neighbouring countries, especially in Italy, Austria and Croatia (Government of the Republic of Slovenia, 2010b, p. 23).

Casinos and gaming halls from Slovenia have different taxes to pay: the special gambling tax, the concession fee and the income tax. The special gambling tax rate amounts to $18 \%$ (ZDIS, 2001). Concession fees are charged separately for each type of special games of chance and they differ between casinos and gaming halls. The latest publicly available data from 2009 revealed that gaming halls payed on average a tax rate of $38 \%$, while casinos payed a tax rate ranging from $23 \%$ to $32.4 \%$ (the tax base is defined separately for each game of chance) (Government of the Republic of Slovenia, 2010b). The listed average tax rates include the gambling tax and the concession fee. Additionally, casinos and gaming halls have to pay also the income tax.

In Croatia, in accordance with the Act on Games of Chance the Ministry of Finance regulates land-based games of chance. Its commitments are (among others): concessions issuing and management, tax and fee collection, and supervision (European Commission, 2019). In Croatia, casinos can be run by private firms. Pursuant to a decision of the Government of the Republic of Croatia, no more than 20 concessions for the organization of special gambling games in casinos (Government of the Republic of Croatia, 2009) and 55 concessions for the organization of gambling machines on automatic machines in clubs may be awarded in Croatia (Government of the Republic of Croatia, 2016). The casino companies from Croatia must pay 500,000 kunas annually (for each casino). In addition to this annual tax, the casino must also pay the gambling tax charged for each game of chance. The tax rate is $15 \%$ (ZIS, 2014). Casinos are also required to pay the income tax.

The specific regulation of the gambling industry applies in Italy. The law prohibits the establishments of casinos, except for those casino firms whose operation is permitted by the law. In Italy, four casinos are treated this way. The most recognized is the casino in Venice. These casinos are owned by local authorities. A large number of slot machines are placed among Italy in bars and clubs (Luin, 2004). In Italy, land-based casinos pay only standard company taxes, since there is no additional gambling taxation. Application license fees for land-based gambling vary according to each government invitation to tender. Therefore, there is no standard application fee (for more details about Italian casinos' taxation see Gambling Capital (2013)).

\section{EMPIRICAL ANALYSIS}

Since gambling is an important branch of the Slovenian tourism industry and the whole economy, the purpose of the study is to determine whether the performance of Slovenian casino firms differs in comparison with their competitors from neighbouring countries (i.e. Croatia and Italy) and which are the largest differences.

\section{DATA AND METHODOLOGY}

To perform the analysis, we obtained financial data for Slovene, Croatian and Italian casino firms for the period 2013-2016 (Slovenian firms, and casino firms from neighbouring countries). The fact that the fiercest competition for Slovene casinos are firms which organize special 
games of chance in neighbouring countries, especially Italy, Austria and Croatia, was stated in the latest „Strategy for the development of gambling” prepared by the Slovenian government (Government of the Republic of Slovenia, 2010b, p. 23). The sample includes 28 Slovenian, 51 Croatian and 4 Italian casino firms.

Financial data for Slovenian casinos were obtained from the GVIN database, while for Croatian and Italian casino firms have been commissioned from Bisnode LLC. The benchmarking analysis is grounded on the DuPont performance measurement system, which emphasis the return on equity - ROE (calculated as net income over average value of equity) ratio as the most important ratio to evaluate firms' performance. A more detailed analysis of business performance was made using ratios that directly affect ROE. These are the ROA (calculated as net income over average value of assets) and the asset-to-equity ratio. The latter indicates the structure of company's financing. Higher ROA leads to higher ROE, while a higher share of equity financing leads to a lower ROE. We have further splitted ROA ratio into net profit margin (calculated as net income over total revenues) and total asset turnover ratio (calculated as total revenues over total assets). Higher are these two ratios (ceteris paribus), higher the ROE. The presented division of ratios follows the DuPont scheme of financial ratios.

For the purpose of hypotheses testing and the analysis of potential differences in performance of selected firms between countries, and due to the characteristics of the sample, a non-parametric Mann-Whitney U-test was used.

The most important limitation of the study refers to the countries included in the analysis. Financial data required for the analysis is payable and can therefore only be obtained to a limited extent. Thus, we could not get the data for Austrian firms, which are also important competitors. Consequently, firms included in the analysis were limited to firms from Slovenia and two neighbouring countries. The second limitation is that our analysis is based on publicly available financial data, since we do not have the access of firms' internal financial data.

The sample of Slovene firms includes 28 firms. Firms included in the sample operate in Standard Classification of Activities R92.001 »Activity of casinos«. Croatian sample includes 51 firms. We included in the sample firms operating in the industry SKD 92.00. ${ }^{5}$ The sample of Italian firms includes all four casinos: Casino di Campione, Casino di San Remo, Casino di Venezia and Casino de la Vallee. Initially, we wanted to include in the Italian sample even those firms that own slot machines in bars and clubs, but their financial data is inappropriate for our analysis, since these firms usually carry out other activities (besides special games of chance). This would make the results of our analysis distorted. This problem is due to the Italian regulation, since casino saloons do not exist in the same form as in Slovenia and Croatia. Therefore, in the Italian case it is the most appropriate to analyse only casino firms. The total sample thus comprises 83 firms.

For 34 firms operating in the gaming industry, financial data were not available. Thus, we could not include these firms in the analysis. In addition, 11 more firms were excluded from the sample because ROE data were not available for the entire period of analysis. Consequently, we retained 51 firms in the sample. However, all 51 firms did not have data for the entire period of analysis. Since only a few data were missing for each year, we kept these firms in the analysis. Furthermore, we noticed that some firms had $0 €$ of sales revenues. Since this indicates that the company did not operate, such a company was removed from the sample in the year when the value of net sales was zero. We eliminated four firms that had sales revenues in all years equal to 0. Finally, 36 firms were retained in the sample for the year 2013, 35 firms for 2014, 44 firms for 2015 and 42 firms for 2016. 
Considering the fact that in Slovenia, the owners of casino firms pointed out that the industry is facing problems due to excess tax burden, we also wanted to analyse the effects of the concession fee and the gaming tax on their business. In the process of our analysis, we have determined that such an analysis is not feasible by using only publicly available data. These duties are presented in the income statement. The amounts of these duties were not disclosed among the data obtained. An additional difficulty for this kind of analysis is the fact that these duties are recorded in different ways by firms from different countries. Therefore, we could not carry out an analysis to determine the level of tax burden arising from the concession fee and the gaming tax.

\section{HYPOTHESIS DEVELOPMENT}

In accordance with statements of the Government of the Republic of Slovenia (2010a) the taxation of casino firms is the most frequently emphasized factor that influences their performance. Due to social unacceptability of negative effects of the gaming industry, income from gaming activities in Slovenia is taxed more than the one in other industries. Casino concessionaires in Slovenia have already highlighted the exhaustion of the industry with an excess tax burden.

It is found that there are significant differences in the taxation of the gaming industry between EU Member States (Swiss Institute of Comparative Law, 2006). Since Slovenia has an above-average taxation on gambling activities (Government of the Republic of Slovenia, 2010a), we expect that the performance of Slovenian casino firms differs from the performance of firms from the same industry in selected neighbouring countries. Since the taxation of Slovenian casino firms is higher than the one in Croatia (Ministry of Finance, Tax Administration, 2018a; Ministry of Finance, Tax Administration, 2018b), in Hypothesis 1 we state:

H1: Slovenian casino firms' business performance is, on average, worse than Croatian once.

Although casino firms' business performance is affected by various factors, we assume that high taxation has the greatest impact on business performance among all factors.

The taxation of the casino industry in Slovenia is also higher compared to Italian one. In Italy, four major casinos do not have a special casino tax (European Casino Association, 2017, p. 62). At the same time, Italian casinos are larger than Slovenian casinos. As found by Assaf et al. (2013) and Day-Yang et al. (2017), the performance of gaming firms is statistically significantly different between firms of different sizes. Assaf et al. (2013) found on the sample of Slovenian firms that larger casino firms were more successful. Therefore, we expect that Italian casinos are more successful than Slovenian, as they are less taxed and much larger than Slovenian casinos. In Hypothesis 2 we state:

H2: Slovenian casino firms' business performance is, on average, worse than Italian ones.

\section{EMPIRICAL ANALYSIS}

\subsection{Descriptive statistics}

Firstly, we present the descriptive statistics of the sample (for details see Appendix 1). Average values and standard deviation were calculated for the most important items from the income statement and the balance sheet, i.e. values of total assets, total equity, net revenues from sales and net income. 
Table 1 shows the descriptive statistics for Slovenian firms. The data shows that in 2016 the average value of total assets of selected Slovenian firms was EUR 11,922,071. It has been declining every year since 2013. The firms in question did not grow on average but reduced business volume. The standard deviation is high, indicating that the value of the assets varies considerably between the firms. This means that the analysed firms from the Slovenian gaming industry differ in size. Assets value differences are especially noticeable between casinos and gaming halls. The average net sales revenues in 2013 and 2016 were $€ 10,583,688$ and $€ 10,287,819$, respectively. Data show that net sales revenues declined. Slovene casino companies recorded losses in three out of four years of our analysis. Net profit was recorded only in 2016. On average, the analysed Slovene firms also did not generate profit in their core business (negative EBIT).

Descriptive statistics for the Croatian casino firms shows that the average value of assets was increasing during the entire period of analysis, reaching an average value of EUR 7,052,704 in 2016. Croatian firms recorded on average a positive net income during the entire period of analysis. The average equity value of Croatian firms more than doubled in the period 2013-2016. In Slovenian firms, however, the average value of equity decreased. Data on average net sales for Croatian firms show that in 2016 compared to 2013 the growth was $18 \%$. In the same period, Slovenian casino firms faced a decrease of the average value of sales revenues.

Similarly, to Croatian firms, even Italian firms recorded a growth of the average value of total assets throughout the analysis period. In 2016 amounted to EUR 132,562,199. If we compare the average values of total assets between the countries concerned, we find that the largest are Italian firms, followed by Slovenian and Croatian firms. The average net sales value also increased in the period 2013-2016. On the other hand, Italian firms on average recorded losses in all four years of our analysis.

\section{RESULTS OF THE EMPIRICAL ANALYSIS}

We started our empirical analysis with a non-parametric Kruskal-Wallis test. With this test, we checked whether there are statistically significant differences in business performance between firms from the three countries included in our analysis, based on the ROE ratio. For the firms included in the analysis, we had 310 ROE data. Seven outliers were excluded from the analysis. Thus, the analysis was performed on $303 \mathrm{ROE}$ data. The non-parametric Kruskal-Wallis test showed that there is a statistically significant difference in ROE between the analysed firms (the significance level is 0.048 , which is less than 0.05 ).

Afterwards, we examined whether there are statistically significant differences in business performance based on the ROE indicator between Slovenian and Croatian firms, and between Slovenian and Italian firms, namely, whether Croatian and Italian firms are more successful than Slovenian firms are.

At first, we tested our first hypothesis. With the non-parametric test, we checked whether there are statistically significant differences between Slovenian and Croatian firms. During the analysis 12 outliers were eliminated. The analysis was performed on 283 data. Descriptive statistics of ROE for the sample of Slovenian and Croatian firms is presented in Table 1. The lowest ROE in the Slovenian sample is $-136.77 \%$, while in the Croatian case is $-114.24 \%$. The highest ROE value in the Slovenian case amounts to $107.65 \%$ and as such is lower than Croatian amounting to $219.20 \%$. 
The non-parametric Mann-Whitney U-test shows that there is a statistically significant difference in ROE between the two countries (the significance level is 0.04, which is less than 0.05). The performance of Slovenian firms operating in the casino industry is on average lower than the performance of firms operating in the Croatian casino industry. The average ROE of Slovenian casinos equals $-0.55 \%$, while the average value of the Croatian firms is, on the contrary, positive at $13.26 \%$ (Table 1$)$.

Table 1. Descriptive statistics for the sample of Slovenian and Croatian firms - ROE (in \%) for the period 2013-2016

\begin{tabular}{lcccccc}
\hline Country & & n & Min. & Max. & Average & St. deviation \\
\hline Slovenia & ROE & 107 & -136.77 & 107.65 & -.55 & 33.10 \\
\hline Croatia & ROE & 176 & -114.24 & 219.20 & 13.26 & 37.55 \\
\hline
\end{tabular}

Source: GVIN, 2018; Bisnode, 2018, and own calculations

Further, we tested the second hypothesis, namely, whether the performance of Slovenian casino firms is on average lower the one of their competitors in Italy. Three outliers were eliminated from further analysis. The test was performed on 124 data.

Table 2. Descriptive statistics for the sample of Slovenian and Italian firms - ROE (in \%) for the period 2013-2016

\begin{tabular}{lcccccc}
\hline Country & & n & Min. & Max. & Average & St. deviation \\
\hline Slovenia & ROE & 109 & -536.68 & 722.09 & 1.15 & 92.57 \\
\hline Italy & ROE & 15 & -666.61 & 861.35 & -37.94 & 327.14 \\
\hline
\end{tabular}

Source: GVIN, 2018; Bisnode, 2018, and own calculations

The non-parametric Mann-Whitney U-test shows that we could not find statistically significant differences in ROE between Slovenia and Italy (the significance level is 0.167 , which is higher than 0.05) (Table 2). Contrary to our expectations, we cannot argue that the performance of the analysed Slovenian and Italian firms differs.

We continue our analysis with a more detailed analysis of the ratios that directly affect ROE. The analysis that follows shows the results of ROA ratio and the share of equity financing. At first, we analyse whether there are statistically significant differences in ROA between firms from Slovenia and Croatia. The basis for our analysis is the sample of firms which was used for the ROE ratio analysis (283 units).

Table 3. Descriptive statistics for the sample of Slovenian and Croatian firms - ROA (in \%) for the period 2013-2016

\begin{tabular}{lcccccc}
\hline Country & & n & Min. & Max. & Average & St. deviation \\
\hline Croatia & ROA & 176 & -52.18 & 90.34 & 7.48 & 20.01 \\
\hline Slovenia & ROA & 107 & -88.45 & 24.34 & -.77 & 15.64 \\
\hline
\end{tabular}

Source: GVIN, 2018; Bisnode, 2018, and own calculations

The average ROA value for Slovenian firms is negative at $-0.77 \%$, while for Croatian firms it is positive at $7.48 \%$. The non-parametric Mann-Whitney U-test shows that there is a statistically significant difference in the average ROA value between Slovenian and Croatian firms (the significance level is 0.017 , which is less than 0.05 ). The average ROA is higher in Croatia, which shows that firms operating in the casino industry earn on average higher returns on invested 
assets than comparable Slovenian firms. A higher ROA, in turn, leads to a higher ROE. A statistically significant difference in ROE between the two countries was already confirmed in the initial stage of our analysis.

Further, we analyse whether there are statistically significant differences in ROA between Slovenian and Italian firms. As shown in Table 4, the lowest ROA in the sample is $-88.45 \%$ and is present in the sample of Slovenian firms. Even in the Italian case the average value is negative, and it amounts to $-14.70 \%$. The highest ROA value is also in Slovenian sample and reaches the value of $24.34 \%$. It is much lower in the Italian case, where it slightly exceeds the zero value and amounts to $0.07 \%$.

Table 4. Descriptive statistics for the sample of Slovenian and Italian firms - ROA (in \%) for the period 2013-2016

\begin{tabular}{lcccccc}
\hline Country & & $\mathbf{n}$ & Min. & Max. & Average & St. deviation \\
\hline Italy & ROA & 14 & -14.70 & .07 & -1.85 & 4.40 \\
\hline Slovenia & ROA & 109 & -88.45 & 24.34 & -.67 & 15.63 \\
\hline
\end{tabular}

Source: GVIN, 2018; Bisnode, 2018, and own calculations

The non-parametric Mann-Whitney U-test shows that there is a statistically significant difference in the average ROA value between Slovenian and Italian firms (the significance level is 0.012, which is less than 0.05) (Table 4). The average ROA value is higher for the Slovenian firms. In both cases, the average ROA value is negative. This is a result of a negative income, which was negative on average for Slovenian firms during the entire period of analysis (the only exception was in 2016). For Italian firms it was negative in all years of our analysis. Unlike the ROE indicator, where we could not confirm the statistically significant differences between Slovenian and Italian firms, in the case of ROA there is a statistically significant difference between the two countries.

Since ROE is also directly influenced by the funding structure, we furthermore analyse whether there are statistically significant differences in the funding structure between countries. To this end, we use the Equity Ratio, which is calculated as the ratio between the value of equity and the value of total capital.

The average value of the ratio in the sample of Slovenian firms is $46.48 \%$ and $65.43 \%$ for Croatian firms. The non-parametric Mann-Whitney U-test shows that there is a statistically significant difference in the average value of the ratio between Slovenian and Croatian firms (Table 5). The results of the analysis show that the average share of equity financing in Croatian firms is higher than in Slovenian firms. A higher share of equity financing leads to a lower ROE.

Table 5. Descriptive statistics for the sample of Slovenian and Croatian firms - share of equity (in \%) for the period 2013-2016

\begin{tabular}{llccccc}
\hline Country & & n & Min. & Max. & Average & St. deviation \\
\hline Croatia & \% of equity & 176 & 9.84 & 100.00 & 65.43 & 26.99 \\
\hline Slovenia & \% of equity & 107 & -66.18 & 91.06 & 46.48 & 26.96 \\
\hline
\end{tabular}

Source: GVIN, 2018; Bisnode, 2018, and own calculations

For Slovenian firms the crucial problem that leads to a lower ROA (compared to Croatian firms) is negative net income (Appendix 1), since Slovenian firms had on average, except for 2016, recorded losses. Negative net income leads to a negative ROA and ROE. 
Furthermore, we analyse whether there are statistically significant differences in the share of equity financing between Slovenian and Italian firms. We found that in both countries there is one company with the negative capital. In the Slovenian case, the lowest ratio value is $-66.18 \%$, while in the Italian case it is $-0.19 \%$. The largest share is also in the Slovenian sample and amounts to $91.06 \%$, in the Italian it reaches $58.08 \%$ (Table 6 ).

Table 6. Descriptive statistics for the sample of Slovenian and Italian firms - share of equity (in \%) for the period 2013-2016

\begin{tabular}{lcccccc}
\hline Country & & $\mathbf{n}$ & Min. & Max. & Average & St. deviation \\
\hline Italy & \% of equity & 14 & -.19 & 58.08 & 22.02 & 18.88 \\
\hline Slovenia & \% of equity & 109 & -66.18 & 91.06 & 45.33 & 28.21 \\
\hline
\end{tabular}

Source: GVIN, 2018; Bisnode, 2018, and own calculations

The non-parametric Mann-Whitney U-test showed the existence of a statistically significant difference in the average value of the equity share between Slovenia and Italy (the significance level is 0.001 which is less than 0.05) (Table 6). The average share of equity financing is higher in the Slovenian case $(45.33 \%)$ compared to Italian firms $(22.02 \%)$.

Although there was no statistically significant difference in the ROE between the Slovenian and Italian firms, we found a significant difference between the two countries in the ROA and the share of equity financing. The average ROA in the Slovenian case proved to be more favourable than the one in the Italian case. As such, it has a positive impact on ROE. On the other hand, higher equity financing ratios (present in Slovenian firms) lead to lower ROEs. Given that the effects of the two ratios on ROE have opposite effects, this may be the reason why the ROE was not significantly different between Slovenia and Italy.

In order to identify the areas in which firms from different countries differ, we analyse the composition of the ROA in more detail. The ROA consists of net profit margin (calculated as net profit or loss in relation to total revenues) and the asset turnover ratio (total revenues divided by total assets). Firstly, we present the results of the analysis of the two indicators for Slovenian and Croatian firms.

We began our analysis for Slovenian and Croatian firms with 283 units, those that were studied in the analysis of the ROE ratio. We excluded 17 outliers, since the values of these units were significantly different from the other values in the sample. Using the non-parametric Mann-Whitney U-test, we found that there is a statistically significant difference between the two countries considering the average values of net profit margin (the significance level is 0.000 , which is less than 0.05). This ratio is higher for Croatian firms compared to Slovenian firms. In the Slovenian case, the average value of this ratio is negative and amounts to $-4.83 \%$, while in the Croatian case it is positive and amounts to $0.52 \%$, which shows that Croatian firms are on average more successful than Slovenian ones.

Table 7. Descriptive statistics for the sample of Slovenian and Croatian firms - Net profit margin ratio (in \%) for the period 2013-2016

\begin{tabular}{lcccccc}
\hline Country & M & Min. & Max. & Average & St. deviation \\
\hline Slovenia & $\begin{array}{c}\text { Net profit } \\
\text { margin }\end{array}$ & 107 & -138.56 & 29.34 & -4.83 & 24.50 \\
\hline Croatia & $\begin{array}{c}\text { Net profit } \\
\text { margin }\end{array}$ & 159 & -308.76 & 78.02 & 0.52 & 48.16 \\
\hline
\end{tabular}

Source: GVIN, 2018; Bisnode, 2018, and own calculations 
Furthermore, we analyse the asset turnover ratio calculated as "total revenues / total assets". We started our analysis with Slovenian and Croatian firms taking into account 283 units (those that were studied in the analysis of the ROE ratio). In the next step, 16 outliers were eliminated, since the values of these units were significantly different from the other values in the sample. Table 8 shows that both the lowest and the highest values of the ratio are present in the sample of Croatian firms. The lowest value is 0.01 and the highest is 4.26.

Table 8. Descriptive statistics for the sample of Slovenian and Croatian firms - Asset turnover ratio for the period 2013-2016

\begin{tabular}{lcccccc}
\hline Country & n & Min. & Max. & Average & St. deviation \\
\hline Slovenia & $\begin{array}{c}\text { Asset } \\
\text { turnover } \\
\text { ratio }\end{array}$ & 107 & .13 & 3.76 & 1.00 & .53 \\
Croatia & $\begin{array}{c}\text { Asset } \\
\text { turnover } \\
\text { ratio }\end{array}$ & 160 & .01 & 4.26 & 1.12 & .87 \\
\hline
\end{tabular}

Source: GVIN, 2018; Bisnode, 2018, and own calculations

The non-parametric Mann-Whitney U-test shows that we cannot find statistically significant differences in the average value of asset turnover ratio (the significance level is 0.526 , which is more than 0.05). The average value of the indicator is 1.00 in the Slovenian case and 1.12 in the Croatian case.

Next, we present the results of the same analysis for the sample of Slovenian and Italian firms. In this case, we started our analysis with 123 units, the same units that were used in the case of ROA analysis. Table 9 shows descriptive statistics for the analysed firms.

Table 9. Descriptive statistics for the sample of Slovenian and Italian firms - Net profit margin ratio (in \%) for the period 2013-2016

\begin{tabular}{lcccccc}
\hline Country & n & Min. & Max. & Average & St. deviation \\
\hline Italy & $\begin{array}{c}\text { Net profit } \\
\text { margin }\end{array}$ & 14 & -71.64 & 6.73 & -15.12 & 22.62 \\
\hline Slovenia & $\begin{array}{c}\text { Net profit } \\
\text { margin }\end{array}$ & 109 & -138.56 & 29.34 & -4.71 & 24.38 \\
\hline
\end{tabular}

Source: GVIN, 2018; Bisnode, 2018, and own calculations

The results of the nonparametric Mann-Whitney U-test show, there is a statistically significant difference in the average value of net profit margin (the significance level is 0.012 which is lower than 0.05). The ratio is higher for Slovenian firms compared to Italian ones. In both cases, the average value is negative, indicating that Slovenian and Italian firms on average did not generate a positive return with recorded revenues.

Table 10 shows the descriptive statistics for the asset turnover ratio for Slovenian and Italian firms. In the Italian case, the average value of the ratio is 0.93 , while in Slovenian case it is slightly higher and amounts to 1.01 .

The non-parametric Mann-Whitney U-test was performed to check if there are statistically significant differences between the two countries. The differences between the samples cannot be confirmed (the significance level is 0.756 which is lower than 0.05 ). 
Table 10. Descriptive statistics for the sample of Slovenian and Italian firms - Asset turnover ratio for the period 2013-2016

\begin{tabular}{ccccccc}
\hline Country & Asset & n & Min. & Max. & Average & St. deviation \\
\hline Italy & $\begin{array}{c}\text { Asrnover } \\
\text { ratio }\end{array}$ & 14 & 0.31 & 1.56 & 0.93 & .56 \\
\hline Slovenia & $\begin{array}{c}\text { Asset } \\
\text { turnover } \\
\text { ratio }\end{array}$ & 109 & 0.13 & 3.76 & 1.01 & .54 \\
\hline
\end{tabular}

Source: GVIN, 2018; Bisnode, 2018, and own calculations

\section{FINDINGS}

The results of our analysis show that changes in the Slovene gaming industry are necessary. Slovenian casino firms, on average, did not perform well in the analysed period 2013-2016. The analysis reveals which areas of business are particularly problematic. They face not only a negative EBIT, but also high interest costs, which has a further negative impact on their overall profit. It is therefore not surprising that in all years of our analysis, with the exception of 2016, they generated a net loss.

Based on the ROE analysis, we found that the performance of Slovenian casino firms is statistically significantly lower than ROE of comparable firms in Croatia. However, we could not prove statistically significant differences in ROE between Slovenian and Italian firms. With a more detailed analysis, we found that Slovenian and Italian firms differ in ROA and share of equity, and further in net profit margin. We have found that the main problem for Slovenian casino firms is that, on average they generate a negative EBIT. At the same time, they also have on average a considerable share of debt financing. Thus, the cost of interests additionally reduces profit or increases loss. For this reason, Slovenian casino firms have to take actions which will improve the performance of their core business. Actions should be taken to monitor operating revenues and operating expenses. There are only two ways to improve EBIT, i.e. by increasing operating revenues or reducing operating costs (expenses). In terms of cost, what matters most is their proper monitoring and subsequent analysis.

The division of the ROA ratio into the net profit margin ratio and the asset turnover ratio in a comparative analysis between Slovenian and Croatian firms showed that Slovenian firms were less successful in terms of net profit margin, while the difference was not found as significant in the case of asset turnover ratio. The net profit margin in the Slovenian case is on average negative due to negative net income. The asset turnover ratio shows that Slovenian and Croatian firms have a similar level of generated revenues with the given extent of invested assets. This indicates that Slovenian firms will have difficulties increasing their operating revenues with a given volume of assets. However, Slovene firms have room to improve the ROA ratio with the increase of the profit margin.

Since data on the amount of concession fees and special gambling taxes were unavailable, we were unable to make a comparative analysis of the effects of these duties on EBIT between countries included in the analysis. The fact is, however, that Slovenian firms had on average a negative EBIT, which is influenced by such duties. Given that the professional public emphasises the problem of excess tax burden in the casino industry, it would be reasonable for the Government to study the effects of such tax burden and determine whether its extent is adequate and allows casino firms to develop in a long-term or is it too high and inhibits their development. 


\section{CONCLUSION}

The gaming industry is an important branch for Slovenian economy in terms of tourism exports, taxes paid by these firms, and as a complement to the tourist offer. Slovenian gaming industry was a flourishing economic activity before the onset of the financial crisis. Since than their performance got worse. Therefore, changes are needed. In 2010, the Slovenian Government adopted the Strategy for the Development of Gambling (Government of the Republic of Slovenia, 2010b), which stated among the policies for a 10-year period the adoption of a stimulating system for gaming duties and the introduction of an active concession policy with a limited number of concessions. We note that to date, Slovenia has not implemented the stated policies.

The results of our analysis show that Slovenian firms specialized in gambling did not perform well in 2013-2016. During the period of analysis, on average they did not increase net sales revenues, at the same time the value of equity and assets decreased. A completely different situation was observed on the sample of Croatian firms. Based on the descriptive statistics of key financial categories, we found that in their case, on average, both equity and assets increased, as did net sales revenues. At the same time net profits were generated in all years of analysis. The situation in Italian casinos, just like in Slovenia, cannot be characterized as successful. Although, in their case, net sales revenues, equity and assets on average increased over the analysed period, Italian casinos on average generated net losses in the whole period of analysis.

In order to determine whether there are statistically significant differences in performance of firms from Slovene, Croatian and Italian casino industry, we performed an empirical analysis. We started our analysis with ROE ratio, which is the basic indicator for assessing business performance in the DuPont performance measurement system. A comparative analysis between the countries concerned showed that there are statistically significant differences in the performance of firms operating in the Slovenian and Croatian casino industry. On average Croatian firms generate higher returns on invested capital than Slovenian firms. A closer analysis showed that a higher ROE in Croatia is due to a higher ROA. The higher ROA, however, is due to a higher net profit margin (we could not confirm the difference in the case of the asset turnover ratio).

On the other hand, we could not confirm statistically significant differences in performance for firms from Slovenia and Italy. Although the ROE did not prove to be statistically significantly different, further analysis showed that the difference between the two countries is significant in the case of ROA and the share of equity financing. Slovenian firms on average generate higher returns on invested assets and have a higher share of equity financing. A higher ROA has a positive effect on ROE, while a higher proportion of equity financing reduces ROE. A more detailed analysis of the ROA ratio further showed that Slovenian firms have on average higher net profit margin, while we could not identify the difference in the asset turnover ratio. In both cases, Slovenian firms were on average more successful.

Based on our findings we provide proposals for improvements for Slovene casino firms. Croatian firms, which we found to be on average more successful than Slovenian firms. Our analysis is, to the best of our knowledge, the first to analyse the performance of Slovenian casino firms, compared to their competitors from abroad. Therefore, the results of our analysis are a good basis for the adoption of measures that will lead to improved business performance of Slovenian casino firms. Future research could analyse the impact of concession fee and special gambling tax on performance of casino firms, since according to the literature these duties have a significant impact. Thus, future research could determine whether revisions of the current taxation system of Slovene gaming industry is needed. 


\section{REFERENCES}

Assaf, G. A., Knezevic Cvelbar L., \& Pahor, M. (2013). Performance drivers in the casino industry: Evidence from Slovenia. International Journal of Hospitality Management, 32, $149-154$.

Bisnode. (2018). Financial data. Retrieved from http: https://www.bisnode.si/

Day-Yang, L., Ya-Chiang, W., Wen-Min, L., \& Cheng-Hsien, L. (2017). The Matthew effect in the casino industry: A dynamic performance perspective. Journal of Hospitality and Tourism Management, 31, 28-35.

Deng, Q., Gu, X., Law, R., \& Lian, Z. (2020) (In Press). A comparative study for determinants of gaming performance in Macao and Las Vegas. Tourism Management, 77.

Eadington, W. R. (2003). The spread of casinos and their role in tourism development. In Tourism Development (pp. 135-150). Routledge.

Eadington, W.R. (2007). Gambling Policy in the European Union: Monopolies, Market Access, Economic Rents, and Competitive Pressures among Gaming Sectors in the Member States. Working Papers 07-005, University of Nevada, Reno, Department of Economics. Retrieved from http://www.business.unr.edu/econ/wp/papers/UNRECONWP07005.pdf

Eadington. W.R. (2011). After the Great Recession: The Future of Casino Gaming in America and Europe. Institute of Economic Affairs, 31(1), 27-33.

European Casino Association. (2015). ECA's European Casino Industry Report 2014. Retrieved from http://www.azarplus.com/fotos/file/ECA_2014_European_Casino_Report.pdf

European Casino Association. (2017). Italy - Casino sector. Retrieved from http://www.europeancasinoassociation.org/country-by-country-report/italy/

European Commission. (2019). Cooperation Arrangement between the gambling regulatory authorities of the EEA Member States concerning online gambling services. Retrieved from https://ec.europa.eu/docsroom/documents/34701

Gambling Capital. (2013). Benchmark of Gambling Taxation and License Fees in Eight European Member States. Retrieved from https://www.tweedekamer.nl/downloads/document?id=b53d39ec-957b-4c51-8760-31554671a428\&title=Advies\%20Gambling\%20Capital.pdf

Government of the Republic of Croatia. (2009). Decision on the number of organizers to whom may be granted the right to organize games of chance in casinos in the territory of the Republic of Croatia. Retrieved from https://narodne-novine.nn.hr/clanci/sluzbeni/ full/2002_11_132_2136.html

Government of the Republic of Croatia. (2016). Decision on the number of organizers to whom may be granted the right to organize games of chance in casinos in the territory of the Republic of Croatia. Retrieved from https://narodne-novine.nn.hr/clanci/sluzbeni/2016_10_92_1954.html

Government of the Republic of Slovenia. (2009). Amendments to the Gambling Act. Retrieved from http://imss.dz-rs.si/imis/c3aecfba9465706cfb97.pdf

Government of the Republic of Slovenia. (2010a). Draft Strategy for the Development of Gambling. Retrieved from www.vlada.si/fileadmin/dokumenti/si/sklepi/seje_vlade/.../112sv2la_gradivo.doc

Government of the Republic of Slovenia. (2010b). Strategy for the Development of Gambling in Slovenia. Retrieved from http://www.fu.gov.si/drugo/posebna_podrocja/igre_na_sreco/

Gu, Z. (2001). Performance Gaps Between U.S. and European Casinos: A Comparative Study. UNLV Gaming Research \& Review Journal, 6(2), 53-62.

Gu, Z., \& Gao, J. Z. (2006). Financial competitiveness of Macau in comparison with other gaming destinations. UNLV Gaming Research \& Review Journal, 10(2), 1. 
GVIN. (2018). Financial data. Retrieved from https://www.bisnode.si/produkti/bisnode-gvin/ Lambert, T., Srinivasan, A., Dufrene, U., \& Min, H. (2010). Urban Location and the Success of Casinos in Five States. International Journal of Management and Marketing Research, 3(3), 1-16.

Luin, D. (2004). Socio-economic aspects of gambling and gambling tourism. Portorož: Turistica, Faculty of Tourism Studies.

Luin, D., \& Hojnik, J. (2016). Gambling Regulation in Slovenia: Adapting Socialist Morality to the European Union Free-Trade Environment. Gaming Law Review and Economics, 17(1), 8-19.

Meich, B. F. (2008). The power to destroy: The psychology of gaming taxation. Gaming Law Review and Economics, 12(5), 458-465.

Ministry of Finance of the Republic of Slovenia. (2018). Special games of chance. Retrieved from http://www.mf.gov.si/delovna_podrocja/igre_na_sreco/posebne_igre_na_sreco/

Ministry of Finance, Tax Administration. (2018a). Games of chance. Retrieved from https://www. porezna-uprava.hr/HR_porezni_sustav/Stranice/naknada_priredjivanje_automati.aspx.

Ministry of Finance, Tax Administration. (2018b). Games in casinos. Retrieved from https://www. porezna-uprava.hr/HR_porezni_sustav/Stranice/naknada_priredjivanje_igre_casino.aspx

Swiss Institute of Comparative Law. (2006). Study of gambling services in the internal market of the European Union. Retrieved from https://ec.europa.eu/growth/content/study-gambling-services-internal-market-european-union-0_sl

ZDIS - Zakon o davku od iger na srečo [Gaming Tax Act]. (2001). Retrieved from http://pisrs. si/Pis.web/pregledPredpisa?id=ZAKO1275

ZIS - Zakon o igrama na sreću [Gambling Law]. (2014). Retrieved from https://www.zakon. $\mathrm{hr} / \mathrm{z} / 315 /$ Zakon-o-igrama-na-sre $\% \mathrm{C} 4 \% 87 \mathrm{u}$ 


\section{Appendix 1.}

Financial data of Slovene casinos and casino salons fort the period 2013-2016 (in €)

\begin{tabular}{|l|l|r|r|r|r|}
\hline \multicolumn{2}{|l|}{ Category } & $\mathbf{2 0 1 3}$ & $\mathbf{2 0 1 4}$ & \multicolumn{1}{|c|}{$\mathbf{2 0 1 5}$} & \multicolumn{1}{|c|}{$\mathbf{2 0 1 6}$} \\
\hline \multirow{3}{*}{ Total assets } & Average & $16,074,581$ & $14,657,807$ & $13,721,819$ & $11,922,071$ \\
\cline { 2 - 6 } Equity & St. deviation & $49,162,493$ & $42,954,051$ & $39,689,559$ & $33,319,601$ \\
\hline \multirow{2}{*}{ Revenues from sales } & Average & $4,976,615$ & $4,925,076$ & $4,699,864$ & $4,611,813$ \\
\cline { 2 - 6 } & St. deviation & $13,445,984$ & $11,225,708$ & $9,825,988$ & $9,715,803$ \\
\cline { 2 - 6 } & Average & $10,583,688$ & $9,893,787$ & $9,895,557$ & $10,287,819$ \\
\cline { 2 - 6 } Net income & St. deviation & $32,097,178$ & $29,725,027$ & $28,874,798$ & $29,822,482$ \\
& Average & $-1,312,995$ & $-501,118$ & $-387,603$ & 457,912 \\
\cline { 2 - 6 } & St. deviation & $6,196,796$ & $1,567,033$ & $2,596,868$ & $1,074,991$ \\
\hline
\end{tabular}

Source: GVIN, 2018, and own calculations

Appendix 2.

Financial data of Croatian casinos and casino salons fort the period 2013-2016 (in €)

\begin{tabular}{|l|l|r|r|r|r|}
\hline \multicolumn{2}{|l|}{ Category } & $\mathbf{2 0 1 3}$ & $\mathbf{2 0 1 4}$ & \multicolumn{1}{|c|}{$\mathbf{2 0 1 5}$} & \multicolumn{1}{|c|}{$\mathbf{2 0 1 6}$} \\
\hline \multirow{3}{*}{ Total assets } & Average & $4,026,705$ & $4,435,038$ & $5,580,189$ & $7,052,704$ \\
\cline { 2 - 6 } & St. deviation & $9,007,972$ & $9,700,109$ & $13,132,659$ & $15,065,268$ \\
\hline \multirow{3}{*}{ Revenuity } & Average & $2,045,640$ & $2,533,278$ & $3,282,512$ & $4,276,337$ \\
\cline { 2 - 6 } & St. deviation & $5,846,756$ & $6,955,149$ & $9,906,527$ & $10,663,271$ \\
\hline \multirow{2}{*}{ Net income from sales } & Average & $6,349,203$ & $6,407,515$ & $5,234,416$ & $7,496,309$ \\
\cline { 2 - 6 } & St. deviation & $14,878,138$ & $14,961,439$ & $12,671,568$ & $16,079,084$ \\
& Average & $1,092,311$ & $1,631,506$ & 820,770 & $1,174,552$ \\
\cline { 2 - 6 } & St. deviation & $5,257,480$ & $7,014,936$ & $3,743,783$ & $4,058,146$ \\
\hline
\end{tabular}

Source: Bisnode, 2018, and own calculations

\section{Appendix 3.}

Financial data of Italian casinos for the period 2013-2016 (in €)

\begin{tabular}{|l|l|r|r|r|r|}
\hline \multicolumn{2}{|l|}{ Category } & \multicolumn{1}{|c|}{$\mathbf{2 0 1 3}$} & \multicolumn{1}{|c|}{$\mathbf{2 0 1 4}$} & \multicolumn{1}{|c|}{$\mathbf{2 0 1 5}$} & \multicolumn{1}{|c|}{$\mathbf{2 0 1 6}$} \\
\hline \multirow{2}{*}{ Total assets } & Average & $96,508,667$ & $104,603,830$ & $128,262,500$ & $132,562,199$ \\
\cline { 2 - 6 } Equity & St. deviation & $89,901,751$ & $77,496,727$ & $100,944,918$ & $76,041,730$ \\
\hline \multirow{2}{*}{ Revenues from sales } & Average & $25,861,667$ & $64,440,084$ & $45,013,915$ & $32,115,224$ \\
\cline { 2 - 6 } & St. deviation & $41,171,625$ & $72,639,024$ & $48,951,642$ & $35,415,648$ \\
\cline { 2 - 6 } Net income & Average & $65,562,000$ & $47,167,500$ & $64,408,869$ & $67,234,136$ \\
\cline { 2 - 6 } & St. deviation & $21,941,241$ & $35,004,073$ & $17,180,001$ & $20,168,079$ \\
\cline { 2 - 6 } & Average & $-8,079,333$ & $-6,018,644$ & $-12,703,567$ & $-13,123,757$ \\
\cline { 2 - 6 } & St. deviation & $11,464,818$ & $9,356,570$ & $16,127,935$ & $22,413,812$ \\
\hline
\end{tabular}

Source: Bisnode, 2018, and own calculations 